\title{
WINTER PREDATION ON AN ERMINE BY A GREAT GRAY OWL
}

DANIEL F. BRUNTON, 2704 Marie Street, Ottawa, Ontario, K2B 7E4 and WILLIAM D. REYNOLDS, Box 453, Perth, Ontario. K7H 3 G1

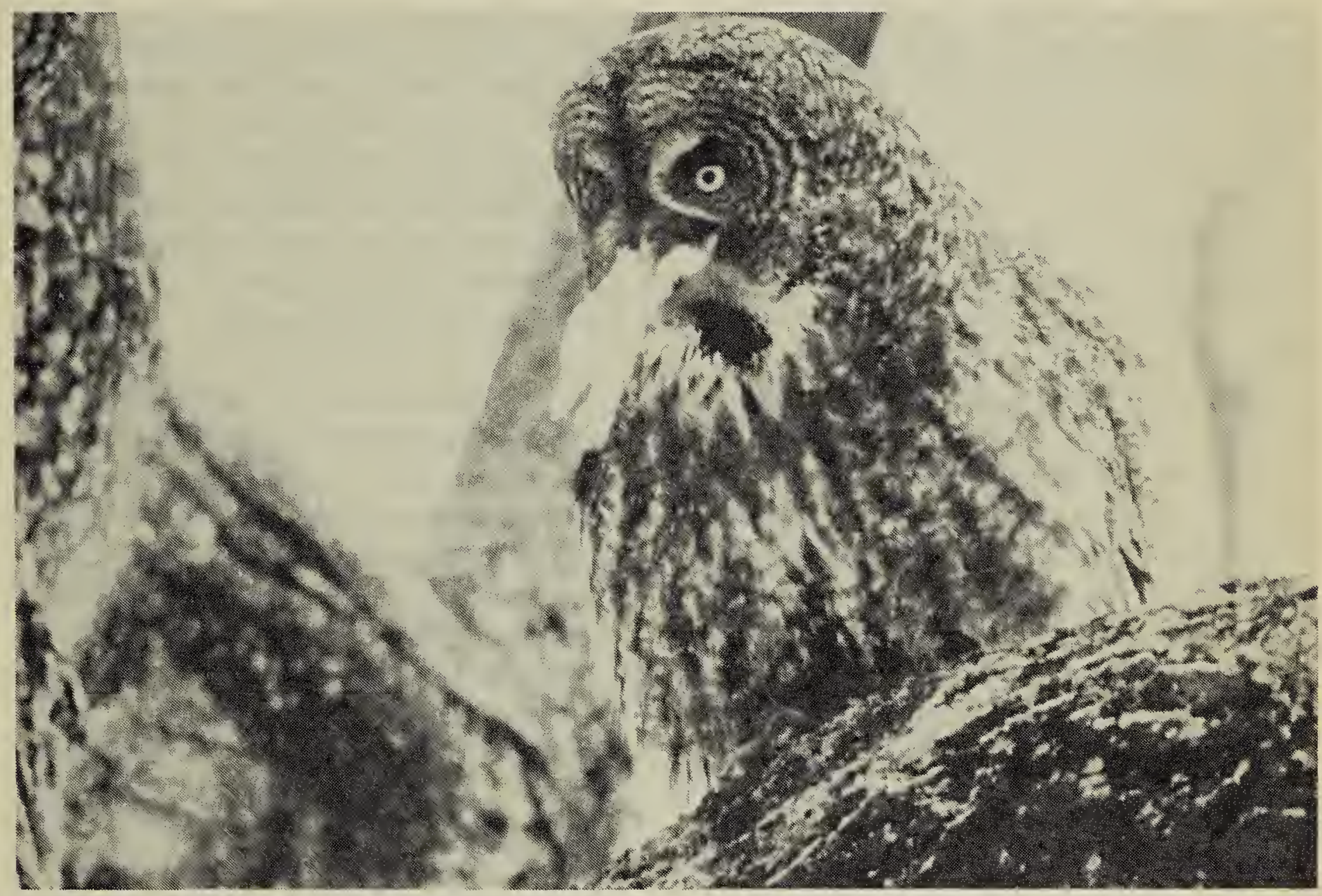

Figure 1. Great Gray Ow/ swallowing hind portion of an Ermine, 11 January 1984, Nepean, Ontario

The Great Gray Owl is primarily a crepuscular predator of small rodents, with the Meadow Vole(Microtus pennsylvanicus) being by far the most common prey species. ${ }^{6}$ Although other prey species have been noted -- varying from dragonflies to Varying Hare these are infrequent and of relatively little overall significance. ${ }^{6}$ Brunton and Pittaway observed a Great Gray attempting to capture an apparently healthy Red Squirrel (Tamiasciurus hudsonicus) which it failed to do after a lengthy struggle. ${ }^{2}$ We are aware of no observations of attacks on larger, healthy animals. Feeding on carrion - or on individuals severely weakened by disease or injury - may well account for the infrequent discovery of remains of larger prey in Great Gray Owl pellets and/or at nest sites. ${ }^{2} 46$ The Great Gray, then, appears to be an opportunistic predator, feeding on any animal that it. can subdue without excessive effort.

In the following, we document the predation by a Great Gray Owl on an Ermine (Mustella erminea cicognanii), one of these larger, rarely detected prey species.

On 11 January 1984 Reynolds, with fellow photographers $H$. Danner and T. Dyke, observed and photographed an adult female Great Gray Owl which 
had been on territory at Shirleys Bay Hamlet, Nepean, Ontario (just west of Ottawa along the Ottawa River) for several weeks. (The sex of the bird, indicated by a wing length measurement of $430 \mathrm{~mm}$, and age were determined by $R$. Poulin of the National Museum of Natural Sciences during banding activities). The owl was roosting in a tree with a dead Meadow Vole in the talons of one foot. At ca. $1000 \mathrm{~h}$ the bird observed an Ermine moving across the snow (which was ca. $0.5 \mathrm{~m}$ deep), flew directly to it, pounced on the weasel and apparently killed it. The Ermine was assumed to be killed immediately by the owl's talons because it did not move after capture nor did the bird lean over and bite its head as Great Grays usually do with mice and voles. ${ }^{2} 6$ Throughout the pursuit and capture, the dead vole remained in the owl's talons. Shortly thereafter, the owl flew to a large, horizontal tree limb with both prey in its talons where it remained for almost an hour, "brooding" the two prey and dozing in the bright morning sunshine. Occasionally the bird would become alert, look around and peck at the weasel but no attempt was made to feed on it. At about $1100 \mathrm{~h}$ the bird became fully alert, turned on its perch (dropping the vole in the process) and, holding the dead weasel in its talons, tore the prey in half with its bill. The fore portion of the weasel was subsequently swallowed whole, followed quickly by the hind portion (Figure 1). The viscera were not removed and the entire prey was swallowed. The breaking up and swallowing of the Ermine took ca: 30 seconds.

As the sex of the Ermine could not be determined, it is difficult to be precise about the weight of the prey. Males (ca. $80 \mathrm{gms}$ ) are much heavier than females (ca. $54 \mathrm{gms}$ ). ' The Ermine gave no indication of weakness or abnormality (beyond that of venturing abroad in day time; it is primarily a nocturnal predator). ${ }^{17}$
Although lighter in weight than a Red Squirrel, the Ermine is a surprising prey because it is itself a predator and predators are not commonly found to be prey species of owls. ${ }^{3}$ Because of its aggressive manner, the Ermine would likely be a more difficult animal (gram for gram) for a Great Gray Owl to subdue than a Red Squirrel. This owl's success may have been largely dependent on its ability to kill the weasel immediately and without a struggle. If previous observations of attacks on Red Squirrel are any judge, we would expect the Ermine to escape from the owl if the struggle were prolonged. ${ }^{2}$

Although Nero lists "weasels" amongst the prey of Great Gray Owls, this is based on the discovery of Ermine remains in a single pellet found at a nest in early 1977 (R. Nero, pers. comm). ${ }^{6}$ The possibility of this representing an owl's feeding on carrion cannot be eliminated and has been documented with Great Grays feeding on the carcasses of Marten (Martes americana). ${ }^{6}$ Mikkola lists Pygmy Weasel (Mustella rixosa) - a smaller species than Ermine - as a rare $(0.8 \%)$ prey item at 61 European nests. $^{5}$

S. Loch found a pregnant Least Weasel (Mustella rixosa) at a Great Gray Owl nest near Hadaskville, Manitoba on 1 May 1984 (R. Nero, pers. comm.).

Nero suggests that Great Grays probably require considerably more than their normal summer food consumption during the more demanding cold periods of winter. ${ }^{6}$ This may encourage the owl to pursue larger prey items (such as the Ermine) at such times. It is interesting to note that the bird in these observations was already holding a prey item (presumably because it was "full" from several others it had caught and eaten prior to $1000 \mathrm{~h}$ ) and maintained pos- 
session of it throughout the chase and capture of the larger prey. It may have been holding on to this vole (rather than storing it) to keep it from freezing. We have watched the bird chase and catch a frozen mouse used as a lure but, upon biting it, the owl would immediately fly off. By 'brooding' the prey, they would remain warm and flexible and in an edible form. As temperatures were between $-23.2 \mathrm{C}$ and $-17.0 \mathrm{C}$ that day (fide Transport Canada Weather Office, Uplands Airport, Ottawa), the prey would have frozen very quickly if exposed to the air. This not only would have made the prey very difficult (if not impossible) for the bird to tear up and eat, it would have used a considerable amount of the owl's core body heat to melt the frozen meat. That, in turn, might be a critical factor affecting a bird's survival during extended cold periods.

Our observations, then, appear to represent the first documented case of a Great Gray Owl being observed to kill and eat an apparently healthy weasel. This Ermine may also represent the largest prey animal actually seen to be killed by a Great Gray Owl.

\section{Acknowledgements}

Our sincere thanks to Bob Nero for providing useful information and important literature references on Great Gray Owls and to Richard Poulin for providing banding data on the bird in question. Thanks too to Helene Danner and Ted Dyke for their company and assistance in the field.

1 BANFIELD, A.W.F. 1974. The Mammals of Canada. University of Toronto Press, Toronto.

2 BRUNTON, D.F. and R.J. PITTAWAY. 1971. Observations of the Great Gray Owl on winter range. Canadian FieldNaturalist 85: 315-322.

${ }^{3}$ CRAIGHEAD, J.J. and F.C. CRAIGHEAD. 1969. Hawks, Owls and Wildlife. Dover Publications, New York.
${ }^{4}$ FISHER, B.M. 1975. Possible intra-specific killing by a Great Gray Owl. Canadian Field-Naturalist 89: 71-72.

${ }^{5}$ MIKKOLA, H. 1983. Owls of Europe. Buteo Press, Vermilion.

${ }^{6}$ NERO, R.W. 1980. The Great Gray Owl: Phantom of the Northern Forest. Smithsonian Inst. Press, Washington.

7 PETERSON, R.L. 1966. The Mammals of Eastern Canada. Oxford Univ. Press, Toronto.

\section{A NOTE ON}

ALBINISM IN THE GREAT GRAY OWL

RENATE SCRIVEN, 722 Buckingham Road, Winnipeg, Manitoba. R3R 1 C2

In a mostly dark-plumaged bird such as the Great Gray Owl the occasional occurrence of white albinistic feathers should be expected and noticed. Lack of the pigment melanin in random feathers (partial albinism) has been reported for numerous species. Nero, for example, noted that practially all of more than 200 adult male Red-winged Blackbirds collected near Madison, Wisconsin, showed depigmentation of some otherwise usually wholly black feathers (Auk 71: 131-135, 1954). Although I made no attempt to search out the literature or to contact museums, albinism in the Great Gray Owl appears to be relatively uncommon. None of more than 150 Great Gray Owls banded in Minnesota by Steven L. Loch showed any albinism (pers. comm., 1984). In the process of lengthy handling of more than 300 live grown owls and about 80 dead ones, Herbert W.R. Copland and Robert W. Nero observed only five birds with abnormal white feathers. These Manitoba records are as follows: 